\title{
Use of Internet by the Research Scholars \& Faculty Members: A Survey Study of Kurukshetra University Kurukshetra in the Disciplines of Science
}

\author{
${ }^{1}$ Anil Kumar (Gold Medalist), ${ }^{2}$ Monika Parmar (Gold Medalist) \\ ${ }^{I}$ (Librarian, Swift Group of Colleges, Rajpura, Patiala (Punjab), India)M.Sc. Library, M. Phil Library \& Inf. Sc. \\ Pursuing Ph. D in K.U.K) \\ ${ }^{2}$ (Asst. Prof. Swift Institute of Mgt \& Computer Science, Rajpura, Patiala (Punjab), India) M.A, M.Phil
} (Economics), UGC Net

\begin{abstract}
The present study has been undertaken to assess the use of Internet by the research scholars and faculty members: A survey study in Kurukshetra University Kurukshetra in the disciplines of Science. A well structured questionnaire was distributed among the research-scholars and teachers of ten departments viz Chemistry, Computer Science \& applications, Electronic Science, Geography, Geology, Geophysics, Mathematics, Physics, Statistics \& operational research and also department of Instrumentation following under the disciplines of science. The responses were gathered from 205 users $(90$ Teachers and 115 Research Scholars).The findings of the survey reveal useful facts about the use of Internet by kurukshetra University kurukshetra.74.63\% of the respondents were always use the Internet daily, $4.87 \%$ were used it sometimes. Only less than $14.63 \%$ respondents were always using the Internet once in a week and also $5.85 \%$ twice in a week. In Science $87.80 \%$ respondents were always use the internet for research works, $12.19 \%$ used it sometimes. Majority of them $73.17 \%$ education and $58.53 \%$ entertainment purpose use the internet their always and $36.58 \%$ sometimes. On the basis of the findings, it was suggested that in order to improve the speed of Internet should be increased so that the respondents can speedily access and their download relevant materials. So provide better provision for the library should organized training programme for the information professionals so that they can know about different search interface, latest changes of the journals site and develop sophisticated searching and retrieval skills or techniques. Most of respondents were suggested that Kurukshetra University Kurukshetra should take necessary steps to utilize the lease line the timing of the Internet section should be extended round the clock. If round the clock was not possible at least up to the working hours of the library and a notice board should be maintained in the Internet section for displaying the Information regarding popular websites \& their addresses.
\end{abstract}

Keywords: E-Resources, E-Database, Information, Internet, Kurukshetra University Kurukshetra, Library, Research, Science, Use.

\section{Introduction}

Information and Communication Technology (ICT) has been making such an impact on different sectors of human activity that the present period has come to be called as information age. Its impact on libraries, their management and services is no less. In the context of library and information management, it has become synonymous with automation and modernization of libraries and information centers. The main objective of University library is to support the educational objectives of the university such as learning, teaching, research and publication. University libraries in India, in general, are not in a position to perform the functions in a satisfactory manner in spite of the fact that majority of the university libraries possess quite a large collection of documents. This may be due to a number of interrelated socioeconomic, cultural \& technological factors. Thus there is a great difficulty to acquire the number of new edition of the books \& to subscribe journals as in the previous year even if the same amount of grant is made available. The price rise in subscription of journals \& books further increase the difficulties. It is difficult to meet that ever growing research \& information needs of the users community in the university sector. In such a scenario, university can heavily depend upon the new information technologies. The internet has great potential for information seekers. It is a means of enhancing \& accelerating scholarly communication, fostering indigenous publications, facilitating computer based learning $\&$ teaching.

Internet facility in India has grown tremendously over the years. The use of internet is rapidly increasing owing to its efficiency \& capability in providing right information to the right person at the right time. It works around the clock \& connects every corner of the world. Internet has become an unavoidable necessarily for every institution of higher learning (Salma and Dominic, 2009). 


\section{Evolution of Internet}

The internet traces its origin to 1960's where it grew out of an experiment conducted by the US Department of Defense. They wanted to create computer network that could continue to function in the event of disaster, such as nuclear war. That network was known as ARPANET (Advanced Research Project Agency Network) which linked with US Scientific Academic Researchers. It was the forerunners of today's internet. 1970's ARPA (Advanced Research Project Agency) helped in the development of new protocols known as TCP/IP (Transmission Control Protocols/Internet Protocols) for transferring data between the networks. The TCP/IP is the core of internet. Internet really took off in 1980's when the National Science Foundation (NSF) used ARPANET to link its four regional super centres at major universities so that many users could share their work. In 1980's Usenet groups \& Electronic mail (E-Mail) came into picture. To give users an easy to use interface to work with, the University of Minnesota created Gopher, a simple menu driven system for accessing files.

Internet really became popular in 1990's after the development of the World Wide Web (WWW). In 1991 CERN (Conceal European Research Nuclear) released WWW, also known as "the web". The CERN developed the protocol based on hyper text Transfer Protocol (HTTP) that made it possible to connect the contents with the web, with the help of hyperlinks. In June 1993 there were only 130 websites, but now there are millions. With the growth of internet, the quality, quantity \& variety of information also grew. Today internet is a repository of every consumable type of information. Nowadays, internet users can get information on all sorts of activities.

\section{Definition of Internet}

ITESL (2007) "The word internet is derived from two words: INTER connection \& NET works. Also referred to as "the Net", Internet is a worldwide system of computer networks, that is, a network of networks, which allows the participants (users) to share information on those linked computers".

Oxford Dictionary The internet is an arrangement of connected computers, which lets the computer users all over the globe exchange data. At the present time, approximately $33 \%$ of the world population has accessibility to the internet. The internet is an extraordinary entertainment \& learning tool that may be utilized in a number of modes to increase the ability of a user to collect information. The principal components of the internet are the WWW \& E-mail. With the passage of time, the internet has become the most effective business tool in the contemporary world. It can be described as a global meeting place where people from every corner of the world can come simultaneously.

\section{Internet Service Provider (ISP)}

ISP is an organization that provides the required software which is used to connect to the Internet. For a monthly for, the ISP provides user software package, username, password \& access phone numbers. Equipped with a modem the user can then log on to the internet $\&$ browse the web.

\section{Getting Connected To Internet}

The basic requirements for getting online are:

* A TCPVIP enabled computer with a web browsers.

* An account with an ISP.

* A telephone line plugged to a suitable socket.

* A modem to connect the computer to the telephone line.

\section{Types of Internet Connection}

The modem need to be connected to a telephone line to access the web. However, modem does not need a special telephone line. Most people use their regular phone line to connect to the internet. Apart from a normal telephone line, we can also use other channels to connect the web.

\section{$>$ Some Modes of Internet Connection are}

* Terminal Dialup/modem (Shell Connection): shell accounts were more popular before the advent of the web. A shell account lets you use your computer much as if it were a virtual console associated with a remote computer. You can type commands, which are interpreted by the remote computer and view the resulting output on your computer.

* SLIP (Serial Line Internet Protocol): is an encapsulation of the internet protocol designed to work over serial ports and modem connections. On personal computer, SLIP has been largely replaced by the point to point protocol (PPP), which is better engineered, has more features and does not requires its IP address configuration to be set before it is established. 
- PPP (Point to Point Protocol): PPP is a protocol for communication between two computer connected by phone line to a server.

- ISDN (Integrated Services digital Network): Most often used to connect remote telecommuters to office LANs requires ISDN phone line access. Faster than analog terminal dialup/modem service. User must have ISDN phone line, ISDN card, communications software, TCP software and SLIP or PPP software multimedia connectivity.

* DIAS: the DIAS offers a wire line solution for high speed symmetrical internet access on the existing telephone lines. It provides an "always on" internet that is permanently available at customer's premises. DIAS combines voice and internet data packets on a single twisted pair wire at subscriber premises that means you can use telephone and surf internet at the same time.

* Cable Modem: the term Cable modem is quite new and refers to a modem that operates over the ordinary cable TV network cables. Basically you just connect the cable TV operator connects a cable modem termination system in his end.

\section{$>$ Digital Subscriber line}

* ADSL (Asymmetric DSL): The connection is faster for receiving data than it is for sending data over the Internet.

* VDSL (Very High bit rate DSL): This is a fast connection, but works only a short distance.

* SDSL (Symmetric DSL): This connection, used mainly by small businesses, doesn't allow you to use the phone at the same time, but the speed of receiving and sending data is the same.

* RADSL (Rate adaptive DSL): This is a variation of ADSL, but the modem can adjust the speed of the connection depending on the length \& quality of the line.

\section{Direct Connections}

* Leased Circuit: most often used to connect sites within a specific organization, such as a university or business requires owning or leasing of cable(from $64 \mathrm{kbps}$ to T-3) users typically connected via Ethernet LANs multimedia connectivity at its fastest.

* Satellite Connections: This connection allows you to download internet files via a satellite connection. This is an efficient method for receiving large web graphics \& other items, but you still need a modem connection for other features. You must purchase 3 the connection hardware as well subscribes to the service.

* Wireless Connections: pages, cellular phones \& personal digital assistants now allow varying levels of internet access, from notification of E-Mail to limited web connections. Many of these services remain in the experimental stage. The PPP connection is called as TCP/IP connection or PSTN dial up connection. ISDN connection is called as ISDN dial up connection.

\section{Internet Services}

The librarians \& information scientists are basically concerned how to get things done on internet instead of how things work the way they do on internet. The basic services on internet is E-Mail \& and the WWW, though some of the other resources available via the net such as newsgroups, conferencing \& FTP, are also interesting ones.

* Electronic Mail: E-Mail is a fast, easy \& inexpensive way to communicate with other internet users around the world. It is one of the basic \& earliest services of the internet $\&$ the most used service on the internet too.

- WWW: WWW is one of the most important services available on internet. The WWW is often referred to as the internet. Web is a part of internet \& it refers to a system of internet server that supports hypertext using a specific internet protocol called HTTP on a single interface. The web servers store all the information in web pages.

* Search Engines: Information in the present day context has become one of the most important necessities of man. Every one today wants to get pin pointed information at short time. For retrieving information quickly form internet, one needs to know from where the required information can be obtained, as the internet in itself is vast. A user of the internet can retrieve the information in two ways: either directly from the web site if the URL is known or the web address of the search engine.

- FTP: file transfer protocol refers to an internet tool that allows you to move a file from one place to another.

* Chatting: on the internet, chatting is talking to other people who are using the internet at the same time you are. Usually this talking is the exchange of typed in messages requiring one site as the repository for the messages and a group of users who take part from anywhere on the internet. 
* Telnet: Telnet, a term used to mean remote login, is the ability to access \& control another computer somewhere on the internet.

- Newsgroups: Newsgroups are international discussion groups that focus on a particular topic \& help in gathering information about that topic. The topics discussed here cover all the fields such as politics, computers, technology, and many more.

* Bulletin Board Services: BBS is similar to news groups. It is a miniature online board system \& is cost effective way to disseminate information in E- format. There work as a store \& forward technology.

\section{Review of Related Literature} of research.

The review of the literature is an important part of scientific approach and is carried out in all the areas

Singh (2014) reviewed studies has been undertaken to identify the use of e-resources by the faculty members and research scholars particularly at department of computer science and mathematics of Jamia Millia Islamia University. The study was based on questionnaire method. The author dealt with observed the problems encountered while accessing e-resources followed by the result of the study which showed that $40(100 \%)$ respondents (faculty members and research scholars) were using e-resources. The major finding of the survey revealed that they were frequently using Internet, Online databases and E-journals whereas few of them were using e-books to access the Information.

Aqil and Ahmad (2012) have conducted a study on the use of the internet by research scholars \& PG students of the science faculty of Aligarh Muslim University. The study was based on questionnaire method. They confirmed that $43.70 \%$ of the respondents used internet in the library while $33.77 \%$ of the users used internet based information services from the department. Most of the respondents of the science faculty used the internet for their research work. They showed that $44.96 \%$ of the users use online journal through J-gate, while 20.15\% access science direct for academic pursuits. More than users are highly satisfied with the internet based information services in comparison to print sources, while the major problem of the respondents was slow speed of internet connection.

Patil (2011) carried out a study on the use of internet in government first grade college libraries in Bidar district. The study was based on structure questionnaire method. He confirmed that majority of the respondents used internet at computer centre. The author dealt with observed that there were no computer \& internet facilities in 7 colleges of the district Bidar. Most of the users were required orientation training programme. Some of the users do not use the information due to lack of awareness \& training.

Thanuskodi and Ravi (2011) Reviewed studies has been undertaken to access the internet were use by researcher scholars of Annamalai University, Annamalainagar. They showed that $67.14 \%$ of the users were familiar with the use of digital resources. Most of the users i.e. $64.28 \%$ were using the digital resources for research purpose. The major finding of the survey revealed a useful fact about the majority of the users opined that the digital resources can never replace the printed resources.

Sukla and Mishra (2011) Reviewed studies has been undertaken to discuss the use of e-resources by researcher scholars of IT, Banaras Hindu University. They showed that all the respondents were aware of eresource \& they all use it. More than $76 \%$ users used it daily, while $22 \%$ used it monthly \& only $2 \%$ used it occasionally. Most of the respondents were i.e. $64 \%$ preferred electronic format, while $34 \%$ preferred both print $\&$ electronic. They also useful fact about the highlighted that majority of the research scholars i.e. $88 \%$ used eresources for their research work. Majority of the researcher scholars i.e. 92\% preferred department for accessing e-resources and while accessing e-resources they found a major problems of low internet connectivity.

Devendra (2010) has conducted a study on the use of the internet services at the University of Agriculture \& Technology, Meerut. He found that most of the library users use the internet daily for the purpose of research and development and to access information quickly. Majority of the users were satisfied with the information available an internet. It examined for the various suggestions to be implemented to improve internet services in the library. Time slots should be increased and printers made available to the faculty. Faculty training programmes were essential for proper use of internet resources. Internet facilities should be improved and upgraded PCs may be installed. CD- ROM/CD writers must be installed for data collection. Internet services should be provided around the clock and broadband facilities should be provided for online journals.

Bhatti (2010) has studied on the internet use among faculty members in the changing higher education environment at the Islamia University Bahawalpur, Pakistan. The study was acquired by using both open\& closed questionnaire method. He revealed that internet has radical impact on the changing higher education environment. It is interesting that internet use among faculty members at the university is much higher than expected. Internet was broadly used for teaching and research purposes. He showed that the faculties of science are making most use of internet facility; however faculty members from other faculties also showed an increased interest into internet resources. 
Sathpathy and Rout (2010) studied on the use of e-resources by the faculty members of CVRCE Bhubaneswar using questionnaire method. They confirmed that faculty members were aware of various types of e- resources databases \& e-journals. They suggested for the improvement in the access facilities with high internet speed \& subscription to more e-resources by the central library.

Salaam and Adwgbore (2010) have examined a study on the internet access \& use by students of private Universities in Ogun State, Nigeria. The study revealed that internet facilities were available in all the private Universities. Access to the internet facilities in these institutions was not free. Use of the internet hindered by irregular power supply \& search engines remain the most used internet tool. This study found out that students were used e-mail for academic purpose more than for business.

Parmeshwar and patil (2009) have carried out a study on the use of the internet by faculty and research scholars of Gulbarga University. They highlighted that the internet was a major source of communication \& dissemination of information in the twenty first century. A large portion of user population in the university were aware about the internet, but they do not know all its techniques \& applications, further, a few users of the university still have no knowledge about the internet, there is need of effective user education. The study highlights that the faculty members have longer experience of using the internet than research and free internet access ware provided by the university. E-journals were the most popular internet services. More than $80 \%$ respondents preferred Google search engine for browsing information.

Birader and Sampath (2008) have examined a study on the use of search engines by research scholars $\&$ faculty members of physics department in university of Karnataka. They found that majority of users i.e. $84.33 \%$ used search engines to retrieve information on the internet \& most frequently used search engines were $72.85 \%$ and yahoo with $53.57 \%$.

Khare \& others (2007) have carried out a survey on using of internet as a source of information by the Ph.d scholars of H.S. Gaur University Sagar, M.P. they showed that the rate of internet use was more in research scholars of science, life science, engineering technology \& management faculties as compared to the faculties of art, social science, law, education and commerce. Among the non users of internet, the number of female research scholar was more as compared to male. The research scholars used the internet for research purpose, entertainment as well as for job search. They suggest that it is an imperative to create awareness about internet among the scholars. They also felt a paramount need of imparting training to the researchers, extension of internet connection to the department \& motivating to use of internet for the research scholars.

Furuholt and Krishansen (2007) investigated regional aspect of internet use in Tanzania. Result showed that use and users of the cafes in three different areas were remarkably uniform, which to some degree described socio economic or demographic aspects of the digital divide between rural urban and parts of developing countries. Results showed that high portion of government employees among the rural users used internet. Female share of internet café users was close to $40 \%$ in the urban areas. Computer games, downloading music, downloading software for amusement, e- shopping, doing business were highly used internet services.

Hinson et al. (2007) conducted study to investigate qualitative impact of internet on the work of lawyers in Ghana. Result showed that $78 \%$ of the lawyers interviewed agree that the internet improved their productivity. $88 \%$ of respondents indicate that the internet was useful as a communication tool, while $76 \%$ considered internet to be very important for getting information. In respect of generating business contacts, it seemed the internet was just as important as brick \& mortar strategies for attracting \& retaining clients.

Husain (2006) investigated the pattern of internet use by faculty including the purpose of its use and its impact on teaching \& research. The majority had been using the computers \& internet since more than five years. They used the internet mostly for e-mail, search engines \& WWW resources mainly for communication, research \& publication. It had helped them to save time. Slow speed, lack of time, \& lack of access from home were major problems found. Most of them were interested in improving their internet use skills through formal training.

Isha Stella (2005) has examined the extent of faculty members \& their use of internet in the University of Benin, Nigeria. She found out that most popular areas of internet usage among faculty members \& determined the role of gender in such usage. Questionnaires made up of 18 liker type items, were distributed to 300 faculty members \& 258 usable copies of the questionnaire were returned \& used for the study. She found that 13 of the items were significant as the most recurring internet usage among faculty members. She observed that there was no significant difference between male \& female users for internet usage. She told that most faculty members use the internet occasionally in their instructional activities.

Hanauer (2004) surveyed a diverse community college to assess the use of internet by students. The survey showed that although all the students surveyed had free internet access through their community college, only $97 \%$ of the students reported having access to the internet. The survey showed that $83 \%$ of internet users had access to internet at their home $\& 51 \%$ of the users accessed the internet at their college library. $81 \%$ of the students reported to access internet most for college work \& $80 \%$ for e-mail/chat. 
Uddin (2003) studied the internet use by academics in Bangladesh. The prime objective of the study was to report the level of internet use by university academics for their information \& communication needs. The survey showed that e-mail was the most commonly used tool by the respondents, WWW $71 \%$, downloading files \& journal 56\% was the next popular service. In terms of using the internet for information publication there was no significant difference between lecturers \& professors. $80 \%$ lecturers \& $21 \%$ professors used internet for higher studies.

Hansa (2000) investigated a study on internet use in Syria. The study showed how internet affected their culture \& Syrian business. It also showed the importance of the internet as a tool for advertising \& electronic commerce.

\section{Research Methodology}

For the purpose of the study, a questionnaire was designed (Appendix-1). The questionnaire was pretested before using it with the survey population. All the respondents were given the same questionnaire irrespective of their status. The questionnaire was distributed to any those respondents who willingly agreed to participate in the study. The respondents were interviewed also to fill in the gaps, if any.

\section{Objectives of the Study}

The present study intends to investigate the following objectives:

* To identify the purpose of using internet by the Teachers and Research Scholars.

* To find the difficulties in browsing the internet based information resources.

* To find out the preferred place for internet usage and time spent per week by the Teachers and Research Scholars.

* To find the impact of internet on research.

* To examine and understand the problem faced by the users to use the internet.

* To explore the extent of internet usage by the teachers and research scholars in the changing environment of higher education

\section{Scope of the Study}

The study is being undertaken in order to identify the use of internet by the research scholars \& faculty members: A survey study in Kurukshetra University Kurkshetra in the disciplines of Science. The study will include research scholars \& faculty of all the ten departments viz Chemistry, Computer Science \& applications, Electronic Science, Geography, Geology, Geophysics, Mathematics, Physics, Statistics \& operational research and also department of Instrumentation following under the disciplines of science.

\section{Statement of the Problems}

Today information technology has developed rapidly \& has a huge impact on access to information. These days all the researchers weather research scholars \& faculty mostly depend on the internet for information gathering for their research. As thousands of periodicals are available on internet either free or on payment and thus literature collection has become quite easy keeping in view these facts the present study is taken up "Use of Internet by the research scholars \& faculty members: A survey study of Kurukshetra University Kurukshetra in the disciplines of Science.

\section{Analysis \& Interpretation}

Table 1. Gender wise use the Internet

\begin{tabular}{|c|l|c|}
\hline S.N & Gender wise & Response No \% \\
\hline 01 & Male & $116(56.58 \%)$ \\
\hline 02 & Female & $89(43.41 \%)$ \\
\hline \multicolumn{2}{|c|}{ Cumulative Total } & $\mathbf{2 0 5}(\mathbf{1 0 0 \%})$ \\
\hline
\end{tabular}

Table 1. shows that use of Internet by the Research scholars \& faculty members in Kurukshetra University Kurukshetra in the disciplines of Science among male and female. Male respondents are $56.58 \%$ than female users which are $43.41 \%$.

Table 2. Status wise Use the Internet

\begin{tabular}{|c|l|c|}
\hline S.N & Status wise & Response No \% \\
\hline 01 & Professor & $32(15.60 \%)$ \\
\hline 02 & Associates Professor & $15(7.31 \%)$ \\
\hline 03 & Asst. Professor & $43(20.97 \%)$ \\
\hline 04 & Research Scholars & $115(56.09 \%)$ \\
\hline
\end{tabular}


Results in Table 2. Show that use of Internet by Kurukshetra University Kurukshetra in the disciplines of Science is more popular among research scholars and junior faculty members. Out of total respondents $56.09 \%$ research scholars, 20.97\% Asst. Professor and than 15.60\% Professor, also 7.31\% Associates Professor are using the Internet.

Table 3: frequency of Use the Internet

\begin{tabular}{|c|c|c|c|c|c|c|c|}
\hline Sr. No & \multicolumn{2}{|c|}{ Use the Internet } & Always & Often & Usually & Sometimes & Never \\
\hline \multirow[t]{2}{*}{01} & \multirow[t]{2}{*}{ Daily } & $\mathbf{T}$ & $30(14.63)$ & $20(9.75)$ & $12(5.85)$ & $10(4.87)$ & - \\
\hline & & R.S & $56(27.31)$ & $20(9.75)$ & $15(7.31)$ & - & - \\
\hline \multirow[t]{2}{*}{02} & \multirow[t]{2}{*}{ Once in a Week } & $T$ & $10(4.87)$ & $8(3.90)$ & $2(0.97)$ & - & - \\
\hline & & R.S & $2(0.97)$ & $3(1.46)$ & $5(0.02)$ & - & - \\
\hline \multirow[t]{2}{*}{03} & \multirow[t]{2}{*}{ Twice in a week } & $\mathbf{T}$ & $4(1.95)$ & $2(0.97)$ & $2(0.97)$ & - & - \\
\hline & & R.S & $1(0.40)$ & $2(0.97)$ & $1(0.40)$ & - & - \\
\hline \multirow[t]{2}{*}{04} & \multirow[t]{2}{*}{ Thrice in a week } & $\mathbf{T}$ & - & - & - & - & - \\
\hline & & R.S & - & - & - & - & - \\
\hline \multirow[t]{2}{*}{05} & \multirow[t]{2}{*}{ Four times in a week } & $T$ & - & - & - & - & - \\
\hline & & R.S & - & - & - & - & - \\
\hline \multirow[t]{2}{*}{06} & \multirow[t]{2}{*}{ Five times in a week } & $\mathbf{T}$ & - & - & - & - & - \\
\hline & & R.S & - & - & - & - & - \\
\hline \multirow[t]{2}{*}{07} & \multirow[t]{2}{*}{ Occasionally } & $\mathbf{T}$ & - & - & - & - & - \\
\hline & & R.S & - & - & - & - & - \\
\hline
\end{tabular}

\section{T= Teacher; R.S= Research Scholars}

Table 3. shows the respondents that various availability available use the Internet. $74.63 \%$ respondents are always using the Internet daily and $4.87 \%$ sometimes. Kurukshetra University Kurukshetra in the disciplines of Science $14.63 \%$ users are always uses the Internet once in a week, and $5.85 \%$ twice in a week.

Table 4: Prefer to Use the Internet

\begin{tabular}{|c|c|c|c|c|c|c|c|}
\hline Sr. No & \multicolumn{2}{|c|}{$\begin{array}{l}\text { Prefer to Use the } \\
\text { Internet }\end{array}$} & Always & Often & Usually & Sometimes & Never \\
\hline \multirow[t]{2}{*}{01} & \multirow[t]{2}{*}{ University Library } & $\mathbf{T}$ & - & - & - & $10(4.87)$ & - \\
\hline & & R.S & $50(24.39)$ & $20(9.75)$ & $15(7.31)$ & $05(2.43)$ & - \\
\hline \multirow[t]{2}{*}{02} & \multirow[t]{2}{*}{ Computer Centre } & $\mathbf{T}$ & - & - & - & - & - \\
\hline & & R.S & - & - & - & - & - \\
\hline \multirow[t]{2}{*}{03} & \multirow[t]{2}{*}{ Department } & $\mathbf{T}$ & 40 (19.51) & $20(9.75)$ & $8(3.90)$ & $2(0.97)$ & \\
\hline & & R.S & $5(2.43)$ & - & - & - & - \\
\hline \multirow[t]{2}{*}{04} & \multirow[t]{2}{*}{ Home } & $\mathbf{T}$ & $10(4.87)$ & $10(4.87)$ & - & - & - \\
\hline & & R.S & $5(2.43)$ & $5(2.43)$ & - & - & - \\
\hline \multirow[t]{2}{*}{05} & \multirow[t]{2}{*}{ Cyber Café } & $\mathbf{T}$ & - & - & - & - & - \\
\hline & & R.S & - & - & - & - & - \\
\hline
\end{tabular}

Table 4. shows that $41.46 \%$ respondents are always using the Internet by Kurukshetra University library and $7.31 \%$ sometimes. Kurukshetra University Kurukshetra in the disciplines of Science $35.60 \%$ respondents are always uses the internet by department. Only $14.63 \%$ users use the Internet by home.

Table 5: Purpose to Use the Internet

\begin{tabular}{|c|c|c|c|c|c|c|c|}
\hline Sr. No & \multicolumn{2}{|c|}{$\begin{array}{l}\text { Purpose to Use the } \\
\text { Internet }\end{array}$} & Always & Often & Usually & Sometimes & Never \\
\hline \multirow[t]{2}{*}{01} & \multirow[t]{2}{*}{ Teaching } & $\mathbf{T}$ & 35 (17.07) & $30(14.63)$ & $10(4.87)$ & $15(7.31)$ & - \\
\hline & & R.S & $5(2.43)$ & $5(2.43)$ & $5(2.43)$ & $10(4.87)$ & - \\
\hline \multirow[t]{2}{*}{02} & \multirow[t]{2}{*}{ Research Work } & $\mathbf{T}$ & $30(14.63)$ & $30(14.63)$ & $20(9.75)$ & $10(4.87)$ & - \\
\hline & & R.S & $65(31.70)$ & $30(14.63)$ & $5(2.43)$ & $15(7.31)$ & - \\
\hline
\end{tabular}


Use of Internet By The Research Scholars \& Faculty Members: A Survey Study of Kurukshetra

\begin{tabular}{|c|l|c|c|c|c|c|c|}
\hline 03 & Education & T & $20(9.75)$ & $25(12.19)$ & $20(9.75)$ & $15(7.31)$ & $10(4.87)$ \\
\cline { 3 - 9 } & & R.S & $30(14.63)$ & $25(12.19)$ & $30(14.63)$ & $20(9.75)$ & $10(4.87)$ \\
\hline 04 & Entertainment & $\mathbf{T}$ & $20(9.75)$ & $10(4.87)$ & $10(4.87)$ & $45(21.95)$ & $5(2.43)$ \\
\cline { 3 - 9 } & & $\mathbf{R . S}$ & $50(24.39)$ & $20(9.75)$ & $10(4.87)$ & $30(14.63)$ & $5(2.43)$ \\
\hline
\end{tabular}

Most of the respondents use the library for more than one purpose. The analysis shows that main purposes of use the Internet are research work. In Science $87.80 \%$ users are always use the Internet for research works and $12.19 \%$ sometimes, and education purpose are the second purpose for which users always use the Internet i.e. 73.17\%. Entertainment are the third purpose for using the library i.e. 58.53\% users always and 36.58\% sometimes. In Science disciplines of $46.34 \%$ users are use the internet by teaching purpose of Kurukshetra University Kurukshetra \& $12.19 \%$ sometimes.

Table 6: Do you use the Internet Services

\begin{tabular}{|c|c|c|c|c|c|c|c|}
\hline Sr. No & \multicolumn{2}{|c|}{$\begin{array}{l}\text { Do you Use the Internet } \\
\text { Services }\end{array}$} & Always & Often & Usually & Sometimes & Never \\
\hline \multirow[t]{2}{*}{01} & \multirow[t]{2}{*}{ Daily } & $\mathbf{T}$ & $10(4.87)$ & $5(2.43)$ & $10(4.87)$ & $20(9.75)$ & - \\
\hline & & R.S & $10(4.87)$ & $10(4.87)$ & $15(7.31)$ & $20(9.75)$ & $10(4.87)$ \\
\hline \multirow[t]{2}{*}{02} & \multirow[t]{2}{*}{2 to 3 times in a week } & $\mathbf{T}$ & $15(7.31)$ & $18(8.78)$ & $5(2.43)$ & - & - \\
\hline & & R.S & $30(14.63)$ & $10(4.87)$ & $10(4.87)$ & - & - \\
\hline \multirow[t]{2}{*}{03} & \multirow[t]{2}{*}{3 to 5 time in a Month } & $\mathbf{T}$ & $2(0.97)$ & $1(0.48)$ & $2(0.97)$ & - & - \\
\hline & & R.S & - & - & - & - & - \\
\hline \multirow[t]{2}{*}{04} & \multirow[t]{2}{*}{ Once in a month } & $\mathbf{T}$ & - & $1(0.48)$ & $1(0.48)$ & - & - \\
\hline & & R.S & - & - & - & - & - \\
\hline
\end{tabular}

In Science disciplines of $42.92 \%$ of the respondents always use the Internet services of 2 to 3 times in a week from Kurukshetra University kurukshetra. Only $29.26 \%$ of the users daily use the Internet services, $19.51 \%$ sometimes and also $4.87 \%$ never use the Internet services of daily purpose. $26.82 \%$ respondents are always using the Internet services of 3 to 5 time in a month from Kurukshetra University kurukshetra in the disciplines of Science.

Table 7: Experience of Internet Use

\begin{tabular}{|c|l|c|c|c|c|c|c|}
\hline Sr. No & \multicolumn{2}{|c|}{$\begin{array}{c}\text { Experience of Internet } \\
\text { Use }\end{array}$} & Always & Often & Usually & Sometimes & Never \\
\hline 01 & Less than 1 years & T & - & - & - & - & - \\
\cline { 3 - 8 } & & R.S & - & - & - & - & - \\
\hline 02 & $2-3$ Years & $\mathbf{T}$ & $2(0.97)$ & $3(1.46)$ & $5(2.43)$ & - & - \\
\cline { 3 - 9 } & & R.S & $5(2.43)$ & $4(1.95)$ & $3(1.46)$ & - & - \\
\hline 03 & $4-5$ years & $\mathbf{T}$ & $10(4.87)$ & $15(7.31)$ & $5(2.43)$ & - & - \\
\cline { 3 - 9 } & & $\mathbf{R . S}$ & $3(1.46)$ & $25(12.19)$ & $40(19.51)$ & - & - \\
\hline 04 & \multirow{2}{*}{6 and above years } & $\mathbf{T}$ & $30(14.63)$ & $10(4.87)$ & $10(4.87)$ & - & - \\
\cline { 3 - 9 } & & R.S & $10(4.87)$ & $15(7.31)$ & $10(4.87)$ & - & - \\
\hline
\end{tabular}

Table 7 shows that maximum of the teachers and research scholar's i.e. $47.80 \%$ are the experience of always using the internet $4-5$ years, $41.46 \%$ of the users are more than 6 years experience of using the Internet from Kurukshetra University kurukshetra in the disciplines of Science. Only $10.73 \%$ of the respondents are using the Internet for 2 to 3 years.

Table 8: Average Time Spent on Surfing the Internet in a week

\begin{tabular}{|c|c|c|c|c|c|c|c|}
\hline Sr. No & \multicolumn{2}{|c|}{$\begin{array}{l}\text { Average time spent on surfing the Internet } \\
\text { in a week }\end{array}$} & Always & Often & Usually & Sometimes & Never \\
\hline \multirow[t]{2}{*}{01} & \multirow{2}{*}{ Less than 1 hour a week } & $\mathbf{T}$ & - & - & - & - & - \\
\hline & & R.S & - & - & - & - & - \\
\hline \multirow[t]{2}{*}{02} & \multirow[t]{2}{*}{ 2-4 hours a week } & $\mathbf{T}$ & $5(2.43)$ & $6(2.92)$ & $8(3.90)$ & - & - \\
\hline & & R.S & $10(4.87)$ & $5(2.43)$ & $10(4.87)$ & $1(0.48)$ & - \\
\hline \multirow[t]{2}{*}{03} & \multirow[t]{2}{*}{ 5-6 hours a week } & $\mathbf{T}$ & $20(9.75)$ & $6(2.92)$ & $9(4.39)$ & - & - \\
\hline & & R.S & $5(2.43)$ & $5(2.43)$ & $4(1.95)$ & - & - \\
\hline 04 & 7-9 hours a week & $\mathbf{T}$ & $5(2.43)$ & $3(1.46)$ & $2(0.97)$ & $2(0.97)$ & - \\
\hline
\end{tabular}


Use of Internet By The Research Scholars \& Faculty Members: A Survey Study of Kurukshetra

\begin{tabular}{|c|l|c|c|c|c|c|c|}
\hline & & R.S & $10(4.87)$ & $5(2.43)$ & $10(4.87)$ & $4(1.95)$ & - \\
\hline 05 & $10-20$ hours a week & T & $10(4.87)$ & $10(4.87)$ & $10(4.87)$ & - & - \\
\cline { 3 - 9 } & & R.S & $20(9.75)$ & $10(4.87)$ & $15(7.31)$ & $1(0.48)$ & - \\
\hline 06 & Over 20 hours a week & T & $1(0.48)$ & $2(0.97)$ & $1(0.48)$ & - & - \\
\cline { 3 - 8 } & & R.S & - & - & - & - & - \\
\hline
\end{tabular}

Table 8. shows that Science teachers and research scholars are spend more times in the Internet. $21.46 \%$ respondents are 2 to 4 hours always spend time on surfing the Internet in a week, $0.48 \%$ respondents are sometimes. Only $23.90 \%$ of the users spend 5 to 6 hours a week and $17.07 \%$ respondents 7 to 9 hours. Most of them $36.58 \%$ Teachers \& Research scholars are spent their more than 10 hours in a week on surfing Internet in the discipline of Science from kurukshetra University Kurukshetra.

Table 9: Do you Use Internet resources

\begin{tabular}{|c|l|c|c|c|c|c|c|}
\hline Sr. No & \multicolumn{2}{|c|}{ Use of Internet Resources } & Always & Often & Usually & Sometimes & Never \\
\hline 01 & \multirow{2}{*}{ E-Books } & T & $20(9.75)$ & $10(4.87)$ & $30(14.63)$ & $30(14.63)$ & - \\
\cline { 3 - 9 } & & R.S & $20(9.75)$ & $40(19.51)$ & $20(9.75)$ & $25(12.19)$ & $10(4.87)$ \\
\hline 02 & \multirow{2}{*}{ E-Journals } & $\mathbf{T}$ & $50(24.39)$ & $20(9.75)$ & $10(4.87)$ & $10(4.87)$ & - \\
\cline { 3 - 9 } & & $\mathbf{R . S}$ & $40(19.51)$ & $30(14.63)$ & $20(9.75)$ & $25(12.19)$ & - \\
\hline 03 & \multirow{2}{*}{ E-database } & $\mathbf{T}$ & $10(4.87)$ & $15(7.31)$ & $10(4.87)$ & $10(4.87)$ & $45(21.9)$ \\
\cline { 3 - 9 } & & $\mathbf{R . S}$ & $10(4.87)$ & $20(9.75)$ & $20(9.75)$ & $21(10.2)$ & $44(21.4)$ \\
\hline 04 & \multirow{2}{*}{ E-Thesis } & $\mathbf{T}$ & $5(2.43)$ & $7(3.41)$ & $10(4.87)$ & $10(4.87)$ & - \\
\cline { 3 - 9 } & & $\mathbf{R . S}$ & $25(12.19)$ & $10(4.87)$ & $10(4.87)$ & $25(12.19)$ & - \\
\hline
\end{tabular}

Table 9. shows the respondents that various availability available use the Internet resources. E-Journals \& E-Books both are the top priority of the respondents in Kurukshetra University Kurukshetra in the disciplines of Science. $68.29 \%$ respondents are always using the E-books under the Internet resources, $26.82 \%$ sometimes and $4.87 \%$ never use it. In Science disciplines of $82.92 \%$ users are always using the EJournals from kurukshetra University Kurukshetra and $17.07 \%$ sometimes. Only $41.46 \%$ respondents are always using the E-database, $15.12 \%$ sometimes and $43.41 \%$ never. In fact $32.68 \%$ teachers \& research scholars are always using the E-thesis and $17.07 \%$ sometimes.

Table 10: Use of Internet Services

\begin{tabular}{|c|c|c|c|c|c|c|c|}
\hline Sr. No & \multicolumn{2}{|c|}{ Use of Internet Services } & Always & Often & Usually & Sometimes & Never \\
\hline \multirow[t]{2}{*}{01} & \multirow[t]{2}{*}{ E-mail } & $\mathbf{T}$ & $50(24.39)$ & $20(9.75)$ & $10(4.87)$ & $10(4.87)$ & - \\
\hline & & R.S & $70(34.1)$ & $10(4.87)$ & $20(9.75)$ & $15(7.31)$ & - \\
\hline \multirow[t]{2}{*}{02} & \multirow[t]{2}{*}{ WWW } & $T$ & $20(9.75)$ & $40(19.51)$ & $10(4.87)$ & $20(9.75)$ & - \\
\hline & & R.S & $40(19.51)$ & $10(4.87)$ & $20(9.75)$ & $30(14.63)$ & $15(7.31)$ \\
\hline \multirow[t]{2}{*}{03} & \multirow[t]{2}{*}{ Chatting } & $\mathbf{T}$ & $10(4.87)$ & $5(2.43)$ & $10(4.87)$ & $50(24.39)$ & $15(7.31)$ \\
\hline & & R.S & $45(21.9)$ & $25(12.19)$ & $30(14.63)$ & $15(7.31)$ & - \\
\hline \multirow[t]{2}{*}{04} & \multirow[t]{2}{*}{ Search Engines } & $\mathbf{T}$ & $20(9.75)$ & $15(7.31)$ & $20(9.75)$ & $35(17.07)$ & - \\
\hline & & R.S & $15(7.31)$ & $25(12.19)$ & $30(14.63)$ & $45(21.9)$ & - \\
\hline \multirow[t]{2}{*}{05} & \multirow[t]{2}{*}{ FTP } & $\mathbf{T}$ & $3(1.46)$ & $4(1.95)$ & $5(2.43)$ & $10(4.87)$ & $30(14.63)$ \\
\hline & & R.S & $5(2.43)$ & $6(2.92)$ & $10(4.87)$ & $10(4.87)$ & $40(19.51)$ \\
\hline \multirow[t]{2}{*}{06} & \multirow[t]{2}{*}{ Discussion Group } & $\mathbf{T}$ & $4(1.95)$ & $6(2.92)$ & $8(3.90)$ & $20(9.75)$ & - \\
\hline & & R.S & $10(4.87)$ & $5(2.43)$ & $2(0.97)$ & $20(9.75)$ & - \\
\hline \multirow{2}{*}{07} & \multirow{2}{*}{ BBS } & $\mathbf{T}$ & $5(2.43)$ & $5(2.43)$ & $6(2.92)$ & $30(14.63)$ & - \\
\hline & & R.S & $4(1.95)$ & $3(1.46)$ & $7(3.41)$ & $40(19.51)$ & - \\
\hline
\end{tabular}

Table. 10 reveal the respondents use of internet by Kurukshetra University Kurukshetra regarding various Internet services. Most of them $87.80 \%$ of the users always use the E-Mail service, $12.19 \%$ sometimes. More than $68.29 \%$ of the respondents are always using the WWW service, $24.39 \%$ sometimes and $7.31 \%$ never use it. $31.70 \%$ of the users sometimes used chatting service, $60.97 \%$ always. Again $60.97 \%$ respondents are always using the search engines service, $39.02 \%$ sometimes. In Science disciplines of Kurukshetra University Kurukshetra $34.14 \%$ respondents never used the FTP, 9.75\% sometimes and also $16.09 \%$ always. Only $17.07 \%$ 
respondents are always using the Internet services of discussion group and $24.39 \%$ sometimes. In fact $34.14 \%$ respondents sometimes used the Bulletin Board Services and 14.63\% always.

Table 11: Prefer to Read your Information

\begin{tabular}{|c|c|c|c|c|c|c|c|}
\hline Sr. No & \multicolumn{2}{|c|}{$\begin{array}{l}\text { Prefer to read your } \\
\text { Information }\end{array}$} & Always & Often & Usually & Sometimes & Never \\
\hline \multirow[t]{2}{*}{01} & \multirow[t]{2}{*}{ PDF } & $\mathbf{T}$ & $50(24.39)$ & $30(14.63)$ & $10(4.87)$ & - & - \\
\hline & & R.S & $40(19.51)$ & $40(19.51)$ & $30(14.63)$ & $5(2.43)$ & - \\
\hline \multirow[t]{2}{*}{02} & \multirow[t]{2}{*}{ HTML } & $\mathbf{T}$ & $10(4.87)$ & $15(7.31)$ & $20(9.75)$ & $5(2.43)$ & - \\
\hline & & R.S & $2(0.97)$ & $5(2.43)$ & $8(3.90)$ & $3(1.46)$ & - \\
\hline \multirow[t]{2}{*}{03} & \multirow[t]{2}{*}{ SGML } & $\mathbf{T}$ & $2(0.97)$ & $4(1.95)$ & $6(2.92)$ & $5(2.43)$ & - \\
\hline & & R.S & $10(4.87)$ & $5(2.43)$ & $3(1.46)$ & $4(1.95)$ & - \\
\hline \multirow[t]{2}{*}{04} & \multirow[t]{2}{*}{ MS-Word } & $\mathbf{T}$ & $30(14.63)$ & $20(9.75)$ & $30(14.63)$ & $10(4.87)$ & - \\
\hline & & R.S & $40(19.51)$ & $30(14.63)$ & $20(9.75)$ & $25(12.19)$ & - \\
\hline
\end{tabular}

Table 11. shows the respondents various availability available use the Internet preferred read of information. PDF \& Ms-Word both are the top priority of the respondents in Kurukshetra University Kurukshetra in the disciplines of Science. Majority of them i.e. $97.56 \%$ users are always using the information in PDF format and $2.43 \%$ sometimes. More than $82.92 \%$ respondents are al ways using the Ms-Word format and $17.07 \%$ sometimes. Only $29.26 \%$ users use the HTML format and $3.90 \%$ sometimes. $14.63 \%$ respondents are using the SGML format and $4.39 \%$ sometimes.

Table 12: Use of Search Engines

\begin{tabular}{|c|c|c|c|c|c|c|c|}
\hline Sr. No & \multicolumn{2}{|c|}{ Use of Search Engines } & Always & Often & Usually & Sometimes & Never \\
\hline \multirow[t]{2}{*}{01} & \multirow[t]{2}{*}{ Google.com } & $\mathbf{T}$ & $50(24.39)$ & $30(14.63)$ & $10(4.87)$ & - & - \\
\hline & & R.S & $40(19.51)$ & $45(21.9)$ & $15(7.31)$ & $15(7.31)$ & - \\
\hline \multirow[t]{2}{*}{02} & \multirow[t]{2}{*}{ Yahoo.com } & $\mathbf{T}$ & $20(9.75)$ & $25(12.19)$ & $15(7.31)$ & $30(14.63)$ & - \\
\hline & & R.S & $25(12.19)$ & $10(4.87)$ & $40(19.51)$ & $40(19.51)$ & - \\
\hline \multirow[t]{2}{*}{03} & \multirow[t]{2}{*}{ Excite.com } & $\mathbf{T}$ & $2(0.97)$ & $3(1.46)$ & $2(0.97)$ & - & - \\
\hline & & R.S & $3(1.46)$ & $4(1.95)$ & $5(2.43)$ & - & - \\
\hline \multirow[t]{2}{*}{04} & \multirow{2}{*}{ Altavista.com } & $\mathbf{T}$ & $3(1.46)$ & $5(2.43)$ & $6(2.92)$ & - & - \\
\hline & & R.S & $5(2.43)$ & $8(3.90)$ & $7(3.41)$ & $2(0.97)$ & - \\
\hline
\end{tabular}

Table 12. shows that only $7.31 \%$ of the users reported that the Google.com are sometimes use while majority of $92.68 \%$ of the respondents that it is always use for their areas of search engines. More than $65.85 \%$ of the Science respondents are always use yahoo search engine and $34.14 \%$ sometimes. Only $9.26 \%$ teachers and research scholars stated that the excite search engine are always used in the Kurukshetra University Kurukshetra. Altavista search engine are always useful to $16.58 \%$ of the respondents in the disciplines of Science.

Table 13: Problems encountered while using the Internet

\begin{tabular}{|c|c|c|c|c|c|c|c|}
\hline Sr. No & \multicolumn{2}{|l|}{$\begin{array}{c}\text { Problem encountered while using } \\
\text { the Internet }\end{array}$} & $\begin{array}{c}\text { Strongly } \\
\text { Agree }\end{array}$ & Agree & $\begin{array}{c}\text { Not } \\
\text { Sure }\end{array}$ & Disagree & $\begin{array}{l}\text { Strongly } \\
\text { Disagree }\end{array}$ \\
\hline \multirow[t]{2}{*}{01} & \multirow[t]{2}{*}{ Slow access speed } & $\mathbf{T}$ & $60(29.26)$ & $20(9.75)$ & $10(4.87)$ & - & - \\
\hline & & R.S & $50(14.63)$ & $45(21.9)$ & $20(9.75)$ & - & - \\
\hline \multirow[t]{2}{*}{02} & \multirow{2}{*}{$\begin{array}{l}\text { Difficulty in finding relevant } \\
\text { Information }\end{array}$} & $\mathbf{T}$ & $50(24.39)$ & $30(14.63)$ & $10(4.87)$ & - & - \\
\hline & & R.S & $40(19.51)$ & $40(19.51)$ & $35(17.07)$ & - & - \\
\hline \multirow[t]{2}{*}{03} & \multirow{2}{*}{$\begin{array}{l}\text { Overload of Information on the } \\
\text { Internet }\end{array}$} & $\mathbf{T}$ & $35(17.07)$ & $50(14.63)$ & $5(2.43)$ & - & - \\
\hline & & R.S & $40(19.51)$ & $70(34.14)$ & $5(2.43)$ & - & - \\
\hline \multirow[t]{2}{*}{04} & \multirow[t]{2}{*}{ Lack of skills in location information } & $\mathbf{T}$ & $10(4.87)$ & $5(2.43)$ & $5(2.43)$ & - & - \\
\hline & & R.S & $3(1.46)$ & $5(2.43)$ & $1(0.48)$ & - & - \\
\hline \multirow[t]{2}{*}{05} & \multirow[t]{2}{*}{ Privacy problem } & $\mathbf{T}$ & $6(2.92)$ & $8(3.90)$ & $9(4.39)$ & - & - \\
\hline & & R.S & $5(2.43)$ & $4(1.95)$ & $5(2.43)$ & - & - \\
\hline
\end{tabular}

Table 13. indicates that $53.65 \%$ of the users are strongly agreed by using the Internet of Kurukshetra University kurukshetra are slow access speed, $31.70 \%$ agree and $14.63 \%$ not sure. $43.90 \%$ of the Science teachers \& 
research scholars are strongly agree reported the difficulty in finding relevant information, $34.14 \%$ agree and $21.95 \%$ not sure with the statement. Only $36.58 \%$ respondents are strongly agree to get the overload of information on the Internet, $58.53 \%$ agree and also $4.87 \%$ not sure with the statement. In fact $6.34 \%$ less than respondents strongly agree with the lack of skills in location of information about Internet and also 5.36\% privacy problem in the field of subjects.

\section{Finding of the Survey}

* Use of Internet by the research scholars \& faculty members in Kurukshetra University kurukshetra in the disciplines of Science users used more by males i.e. by $56.58 \%$ than female users.

* Use of Internet by Kurukshetra University Kurukshetra in the disciplines of Science research scholars 56.09\%, 20.97\% Asst. Professor and 15.60\% Professor, also 7.31\% Associates Professor were using the Internet.

* $74.63 \%$ respondents were always using the Internet daily and $4.87 \%$ sometimes.

- Kurukshetra University Kurukshetra in the disciplines of Science $14.63 \%$ users were always uses the library once in a week, and $5.85 \%$ twice in a week.

* $41.46 \%$ respondents were always using the Internet by Kurukshetra University library and $7.31 \%$ sometimes.

* Kurukshetra University Kurukshetra in the disciplines of Science $35.60 \%$ respondents were always uses the internet by department and only $14.63 \%$ users use the Internet by home.

* In science $87.80 \%$ users were always using the Internet for research works and $12.19 \%$ sometimes.

* Education purpose was the second for which users always using the Internet i.e. $73.17 \%$.

- Entertainment were the third purpose for using the library i.e. $58.53 \%$ users always and $36.58 \%$ sometimes.

* In Science disciplines of $46.34 \%$ users were using the Internet by teaching purpose of Kurukshetra University Kurukshetra \& $12.19 \%$ sometimes.

* $42.92 \%$ of the respondents were always using the Internet services of 2 to 3 times in a week from Kurukshetra University kurukshetra. Only $29.26 \%$ of the respondents were daily using the Internet services, $19.51 \%$ sometimes and also $4.87 \%$ never with the statement.

* In fact $26.82 \%$ respondents were always using the Internet services of 3 to 5 time in a month from Kurukshetra University kurukshetra in the disciplines of Science.

* In Science disciplines of $47.80 \%$ respondents were the experience of always using the Internet 4-5 years.

- $41.46 \%$ of the users were more than 6 years experience of using the Internet from Kurukshetra University kurukshetra in the disciplines of Science.

* Only $10.73 \%$ of the respondents were less than 2 to 3 years experience of using the Internet.

* Science teachers and research scholars were more time spends in the Internet. $21.46 \%$ respondents were 2 to 4 hours always time spends on surfing the Internet in a week, $0.48 \%$ respondents were sometimes.

* In fact $23.90 \%$ of the users spend 5 to 6 hours a week and also $17.07 \%$ respondents were 7 to 9 hours time spend in a week from Kurukshetra University Kurukshetra in the disciplines of Science.

* Most of them 36.58\% Teachers \& Research scholars were spent their more than 10 hours in a week on surfing Internet.

* The respondents various availability available use the Internet resources. E-Journals \& E-Books both were the top priority of the respondents in Kurukshetra University Kurukshetra in the disciplines of Science. $68.29 \%$ respondents were always using the E-books under the Internet resources, $26.82 \%$ sometimes and $4.87 \%$ never.

* In Science disciplines majority of $82.92 \%$ users were always using the E-Journals from Kurukshetra University Kurukshetra and $17.07 \%$ sometimes.

* $41.46 \%$ respondents were always using the E-database under the internet resources, $15.12 \%$ sometimes and $43.41 \%$ never. In fact $32.68 \%$ teachers \& research scholars were always using the Ethesis and $17.07 \%$ sometimes.

* Most of them $87.80 \%$ of the users were always used the E-Mail service, $12.19 \%$ sometimes.

- In Science $68.29 \%$ of the respondents were always used the WWW service, $24.39 \%$ sometimes and $7.31 \%$ never. Only $31.70 \%$ of the users sometimes used chatting service, $60.97 \%$ always.

* $60.97 \%$ respondents were always used the search engines service, $39.02 \%$ sometimes.

* In Science disciplines of Kurukshetra University Kurukshetra 34.14\% respondents never used the FTP, $9.75 \%$ sometimes and also $16.09 \%$ always.

- Only $17.07 \%$ respondents were always used the Internet services of discussion group and $24.39 \%$ sometimes. In fact $34.14 \%$ respondents sometimes used the Bulletin Board Service and $14.63 \%$ always.

- Majority of them i.e. $97.56 \%$ users were always using the information of PDF format and $2.43 \%$ sometimes.

* More than $82.92 \%$ respondents were always using the Ms-Word format and $17.07 \%$ sometimes. 
* Only $29.26 \%$ users were using the HTML format and $3.90 \%$ sometimes. Less than $14.63 \%$ respondents were using the SGML format and $4.39 \%$ sometimes.

* Less than $7.31 \%$ of the users reported that the Google.com were sometimes use while majority of $92.68 \%$ of the respondents that it was always use for their areas of search engines.

* $65.85 \%$ of the Science respondents used those yahoo search engine were always and $34.14 \%$ sometimes.

* Only $9.26 \%$ teachers and research scholars stated that the excite search engine were always used in the Kurukshetra University Kurukshetra. AltaVista search engine were also always useful to $16.58 \%$ of the respondents in the disciplines of Science.

* $53.65 \%$ of the users were strongly agreed by using the Internet of Kurukshetra University kurukshetra were slow access speed, $31.70 \%$ agree and $14.63 \%$ not sure.

* $43.90 \%$ of the Science teachers \& research scholars were strongly agree reported the difficulty in finding relevant information, $34.14 \%$ agree and $21.95 \%$ not sure with the statement.

- Only $36.58 \%$ respondents were strongly agreed to get the overload of information on the Internet, $58.53 \%$ agree and also $4.87 \%$ not sure.

- In fact $6.34 \%$ less than respondents strongly agree with the lack of skills in location of information about Internet and also $5.36 \%$ privacy problem in the field of subjects.

Based on the findings, the following Suggestions are put forward to improve the marketing of information products and services in kurukshetra university library.

* The speed of Internet should be increased so that the respondents can speedily access and their download relevant materials.

* Library should organize training programme for the information professionals so that they can know about different search interface, latest changes of the journals site and develop sophisticated searching and retrieval skills or techniques.

* Availability of network on Saturdays evening hours and holidays was very poor. It should be improved.

* To utilize the lease line the timing of the internet section should be extended round the clock. If round the clock was not possible at least up to the working hours of the library.

* A notice board should be maintained in the Internet section for displaying the information regarding popular websites \& their addresses.

* The printing facility should be provided at nominal charges in the Internet section so that users can take outs of important literature and work.

\section{Acknowledgements}

First and foremost, I would like to thank the almighty God (Jesus Christ) the most beneficent and merciful, who blessed me for completing this work. It is not possible to record in words the inspirational guidance of my father Sh. Som Nath kapoor, Mother Shanti devi \& also Brother Dr. Ajay Kapoor. I am also thanks to my sister Meenakshi Kapoor (English lecturer) and Tarun Bhasin the inspirational \& motivational guidance.

\section{References}

[1]. A. Hansa. The Internet in Syria. Online Information Review 24(2), 2000, 144-149.

[2]. A. A. Husain. Internet use by the faculty members of Kuwait University. The Electronic Library 24(6), 2006, $791-803$.

[3]. Aqil. Mohammad and P. Ahmad. Use of the Internet by research scholars and post graduate students of the science faculty of Aligarh Muslim University. 2012 [Cited 21 Sept. 2013] Available from http//unllib.unl.edu/LPP/adil-Ahmad.pdf.

[4]. B.S. Birader and B.T. Sampath. Use of search engines by research scholars and faculty members of Physics department in the Universities of Karnataka state. Annals of Library and Information Studies 55, 2008, 62-68.

[5]. D. Hanauer. Internet use among community college students: Implications in designing healthcare intervention. Journal of American College Health 52(5), 2004, 197-202.

[6]. D.B. Patil. Use of the Internet in government first grade college libraries in Bidar district. 2011 [Cited 21 Sept. 2013] Available from http//unllib.unl.edu/LLP/patil.htm

[7]. Devendra Kumar. Faculty use of Internet services at a University of Agriculture and Technology: New Delhi. 2010 Available from http//faqs.org/periodicals/201002/2025366891.html

[8]. Furuholt and Kristiansen. A Rural Urban digital divide? Regional aspects of Internet use in Tanzania. In proceedings of the $9^{\text {th }}$ International Conference on Social Implication of Computer in Developing Countries: Brazil 15 to 19 May. 2007

[9]. Hinson et al. The Internet and Lawyers in Ghana: some initial qualitative perspectives. Library review 56(4), 2007, 311-322.

[10]. Isha Stela. Extent of faculty members and their use of internet in the University of Benin: Nigeria. 2005. Available from http//highbeam.com/doc/1G1-140412138.html

[11]. ITESL. Introduction to information technology. Pearson: New Delhi, 2007.

[12]. K. Salma and J. Domenic. Use of Internet by the faculty members of engineering colleges of Moradabad: A comparative study. [cited 25 sept.2013] Available from http://crl.du.in/ical09/papers/index_files/ical95_124_278-1-RV.pdf

[13]. Khare et al. Internet as a source of information: A survey of Ph. D scholars. Annals of Library and Information Studies 54, 2007, 80-86. 
[14]. M.N. Uddin. Internet use by University academics: A biparitite study of information and communication needs. Online Information Review 27(4), 2003, 225-237.

[15]. M.O. Salaam and A.M. Adegbore. Internet access and use by students of private Universities in Ogun State: Nigeria. 2010. [Cited 21 Sept. 2013] Available from http// webpages.uidaho.edu/mbolin/salaamasegbore.htm

[16]. P. Sukla and R. Mishra. Use of E-resources by research scholars of Institute of Technology. Banaras Hindu University. 2011. [Cited 21 Sept. 2013] Available from http//researchersworld.com/vol2/issue2/Paper_17.pdf

[17]. R. Bhatti. Internet use among faculty members in the changing higher education environment at the Islamia University of Bahawalpur: Pakistan. 2010 [Cited 21 Sept. 2013] Available from http//webpages.uidaho.edu/mbolin/bjatti3.html

[18]. S. Prameshwar and D.B. Patil. Use of Internet by faculty and research scholars at Gulbarga University Library. 2009 [Cited 21 Sept. 2013] Available from http//webpages.uidaho.edu/mbolin/parameshwar-patil.htm

[19]. S. Thanuskodi and S. Ravi. Use of digital resources by faculty and research scholars of Manonmanian Sundranar University. Tirunelveli. DESIDOC Journal of Library and Information Technology 31(1), 2011, 25-30

[20]. S.K. Satpathy and B. Rout. Use of E-resources by the faculty members with special reference to CVRCE, Bhubaneswar. DESIDOC Journal of Library and Information Technology 47(3), 2010, 321-324.

[21]. V. Singh. Use of E-Resources by the faculty members and research scholars of department of computer science and mathematics of Jamia Millia Islamia University, Delhi: A study. Library Progress 33(2), 2014, 235-250

\section{About Author}

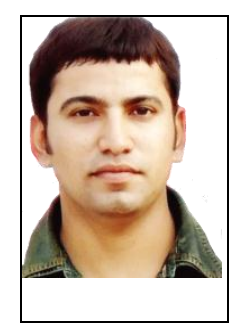

Anil kapoor is presently Librarian (H.O.D in Library) in the Swift group of Colleges Rajpura, Patiala. He holds a Ph.D (Pursuing) in Library \& Information science from Kurukshetra University Kurukshetra. He published than 3 research paper in National \& International professional journals.

E-Mail: anilkapoorkapoor@ rediffmail.com

\section{Appendix - 1}

\section{Questionnaire for Users}

\section{Personal Information}

Name:

Department:

Sex: Female/Male

Status: (tick one): Professor/Reader/Lecturer/Research scholar

\section{Use of Internet}

\section{* Do you Use the Internet?}

\begin{tabular}{|l|l|l|l|l|l|}
\hline Use the Internet & Always & Often & Usually & Sometimes & Never \\
\hline Daily & & & & & \\
\hline Once in a Week & & & & & \\
\hline Twice in a week & & & & & \\
\hline Thrice in a week & & & & & \\
\hline Four times in a week & & & & & \\
\hline Five times in a week & & & & & \\
\hline Occasionally & & & & & \\
\hline
\end{tabular}

\section{* Where do you use/prefer to use Internet}

\begin{tabular}{|c|c|c|c|c|c|}
\hline Prefer to use Internet & Always & Often & Usually & Sometimes & Never \\
\hline University Library & & & & & \\
\hline Computer Centre & & & & & \\
\hline Department & & & & & \\
\hline Home & & & & & \\
\hline Cyber Café & & & & & \\
\hline
\end{tabular}

\section{* Purpose of using Internet}

\begin{tabular}{|l|l|l|l|l|l|}
\hline Purpose of using Internet & Always & Often & Usually & Sometimes & Never \\
\hline Teaching & & & & & \\
\hline Research Work & & & & & \\
\hline Education & & & & & \\
\hline Entertainment & & & & & \\
\hline
\end{tabular}


* How often do you Use Internet Services?

\begin{tabular}{|l|l|l|l|l|l|}
\hline Use the Internet Services & Always & Often & Usually & Sometimes & Never \\
\hline Daily & & & & & \\
\hline 2 to 3 times in a week & & & & & \\
\hline 3 to 5 time in a Month & & & & & \\
\hline Once in a month & & & & \\
\hline
\end{tabular}

\section{Experience of Internet Use?}

\begin{tabular}{|l|l|l|l|l|l|}
\hline Experience of internet use & Always & Often & Usually & Sometimes & Never \\
\hline Less than 1 years & & & & & \\
\hline 2-3 Years & & & & & \\
\hline $4-5$ years & & & & & \\
\hline 6 and above years & & & & & \\
\hline
\end{tabular}

* Average time spent on surfing the Internet in a week?

\begin{tabular}{|l|l|l|l|l|l|}
\hline Time Spent & Always & Often & Usually & Sometimes & Never \\
\hline Less than 1 hour a week & & & & & \\
\hline 2-4 hours a week & & & & & \\
\hline 5-6 hours a week & & & & & \\
\hline 7-9 hours a week & & & & & \\
\hline 10-20 hours a week & & & & & \\
\hline Over 20 hours a week & & & & & \\
\hline
\end{tabular}

* Do you use Internet Resources?

Yes/No

If, yes which of the following resources you regularly use

\begin{tabular}{|l|l|l|l|l|l|}
\hline Use Internet Resources & Always & Often & Usually & Sometimes & Never \\
\hline E-Books & & & & & \\
\hline E-Journals & & & & & \\
\hline E-database & & & & & \\
\hline E-Thesis & & & & & \\
\hline
\end{tabular}

Use of Internet Services

\begin{tabular}{|l|l|l|l|l|l|}
\hline Internet Services & Always & Often & Usually & Sometimes & Never \\
\hline E-mail & & & & & \\
\hline WWW & & & & & \\
\hline Chatting & & & & & \\
\hline Remote login (Telnet) & & & & & \\
\hline FTP & & & & & \\
\hline Discussion Group & & & & & \\
\hline BBS & & & & & \\
\hline
\end{tabular}

In what format would you prefer to Read your Information?

\begin{tabular}{|l|l|l|l|l|l|}
\hline Format use read your information & Always & Often & Usually & Sometimes & Never \\
\hline PDF & & & & & \\
\hline HTML & & & & & \\
\hline SGML & & & & & \\
\hline Ms Word & & & & & \\
\hline
\end{tabular}

Ms Word

Which Search Engine do you Use?

\begin{tabular}{|l|l|l|l|l|l|}
\hline Search Engine & Always & Often & Usually & Sometimes & Never \\
\hline Google.com & & & & & \\
\hline Yahoo.com & & & & & \\
\hline Excite.com & & & & & \\
\hline Altavista.com & & & & & \\
\hline Any other (Pl. Specify) & & & & & \\
\hline
\end{tabular}

What Problems do encountered while using the Internet?

\begin{tabular}{|l|l|l|l|l|l|}
\hline Problem face by using the Internet & Always & Often & Usually & Sometimes & Never \\
\hline Slow access speed & & & & & \\
\hline Difficulty in finding relevant information & & & & & \\
\hline Overload of information on the Internet & & & & & \\
\hline
\end{tabular}




\begin{tabular}{|l|l|l|l|l|l|}
\hline Lack of skills in location information & & & & & \\
\hline Privacy problem & & & & & \\
\hline
\end{tabular}

* Any other suggestion to improve the Internet services in Kurukshetra University kurukshetra.

Thanks for your cooperation
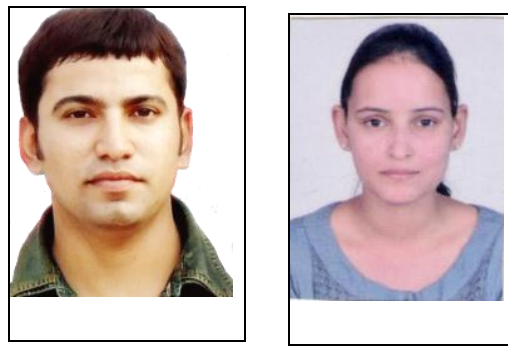

anilkapoorkapoor@rediffmail.com

mcparmar8629@gmail.com 